\title{
PENGARUH PELUANG INVESTASI, DIVIDEND POLICY DAN RASIO TINGKAT PENGEMBALIAN MODAL TERHADAP PRICE BOOK VALUE
}

(Studi Kasus Perusahaan Manufaktur Periode 2010 - 2014)

\author{
Sairin \\ Staf Pengajar Fakultas Ekonomi Universitas Pamulang \\ Email: sairin_irin@yahoo.co.id
}

\begin{abstract}
ABSTRAK
Tujuan dari penelitian ini adalah untuk mengetahui "pengaruh secara parsial antara peluang investasi (investment opportunity set) terhadap price book value", untuk mengetahui pengaruh secara parsial antara dividend policy (kebijakan deviden) terhadap price book value, untuk mengetahui pengaruh secara parsial antara variabel rasio tingkat pengembalian modal (return on equity) terhadap price book value". Penelitian ini menggunakan data sekunder yang didapat berdasarkan laporan keuangan di perusahaan manufaktur yang terdaftar di bursa efek Indonesia (BEI) pada periode 2010 - 2014. Sampel dalam penelitian ini adalah sebanyak 36 perusahaan. Hasil penelitian menunjukkan bahwa terdapat pengaruh secara parsial antara peluang investasi (investment opportunity set), dividend policy (kebijakan deviden) dan rasio tingkat pengembalian modal ( return on equity) berpengaruh terhadap price book value. Hasil penelitian ini juga menunjukkan peluang investasi (investment opportunity set),dividend policy (kebijakan deviden) dan rasio tingkat pengembalian modal (return on equity) berpengaruh terhadap price book value secara bersama-sama (simultan). "Pada koefisien determinasi terdapat pengaruh sebesar 52,2\% yang mempengaruhi price book value yang dijelaskan oleh variable peluang inestasi (investment opportunity set), dividend policy (kebijakan deviden) dan rasio pengembalian modal (return on equity), sedangkan sisanya $47,8 \%$ dipengaruhi oleh variabel lain yang tidak terdapat dalam penelitian ini”.
\end{abstract}

Kata kunci: peluang investasi, dividend policy, rasio pengembalian modal, price book value.

\begin{abstract}
The purpose of this study was to determine "the effect of investment opportunity set on price book value partially, to determine the partial effect of dividend policy on price book value, to find out the effect partially between variable rate of return ratios capital (return on equity) to price book value”. This study uses secondary data obtained based on financial statements in manufacturing companies listed on the Indonesia stock exchange (IDX) in the period 2010 - 2014. The sample in this study were 36 companies. The results of the study show that there is a partial influence between investment opportunity set, dividend policy and return on equity ratio that affect the price book value. The results of this study also indicate investment opportunities (set opportunity), dividend policy (dividend policy) and capital return ratio (return on equity) affect the price book value together (simultaneous). "In the coefficient of determination there is an influence of $52.2 \%$ which affects the price book value explained by investment opportunity sets, dividend policy and return on equity, while the remaining $47.8 \%$ is influenced by other variables not found in this study".
\end{abstract}

Keywords: investment opportunities, dividend policy, capital return ratio, price book value. 
JURNAL ILMIAH

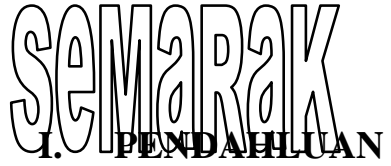

\section{A. Lataar Beelakang Penelitian}

Perusahaan bertujuan untuk memaksimalkan kekayaan pemegang saham dengan memaksimalkan nilai saham perusahaan. "Tujuan ini bukan hanya kepentingan pemegang saham, tetapi juga akan memberikan manfaat terbaik bagi masyarakat" (Keown et al., 2004: 3 - 4). "Tujuan utama perusahaan adalah untuk meningkatkan nilai perusahaan melalui peningkatan kesejahteraan pemilik atau pemegang saham" (Brigham dan Houston, 2009: 19). "Kemakmuran pemegang saham tercermin dalam harga saham di pasar modal. Semakin tinggi harga saham, semakin besar pula kesejahteraan pemilik perusahaan" (Djabid, 2009: 249).

"Pembentukan syarikat harus memiliki tujuan yang jelas. Ada beberapa perkara yang menasihatkan tujuan mendirikan syarikat ". "Tujuan pertama syarikat adalah untuk mencapai manfaat maksimal atau manfaat maksimal". Tujuan kedua syarikat adalah untuk mensejahterakan pemilik perusahaan atau pemegang saham. Sedangkan tujuan ketiga syarikat adalah memaksimalkan nilai perusahaan yang tercermin dalam harga sahamnya. "Tiga tujuan syarikat tidak terlalu berbeza. Hanya saja penekanan yang ingin dicapai oleh masing-masing perusahaan berbeda satu sama lain" (Martono dan Harjito, 2005).

Menurut agensi teori, "penyebab konflik antara manajemen dan pemegang saham termasuk membuat keputusan yang berkaitan dengan cara di mana dana diperoleh dan kemudian diinvestasikan". "Konflik antara pengurus dan pemegang saham dapat diminimalkan melalui mekanisme pemantauan yang dapat menyelaraskan kepentingan terkait ini". "Tetapi dengan munculnya pemantauan mekanisme, itu akan menyebabkan biaya, yang disebut agen biaya. Kos agensi boleh dikurangi dengan meningkatkan nilai hutang (modal struktur) dan dengan meningkatkan dividen dividen pembayaran. Semakin banyak saham yang dimiliki oleh pengurus, masalah agensi akan semakin berkurangan, sehingga dividen tidak boleh dibayar dengan risiko tinggi" (Pearce dan Robinson, 2008).

"Salah satu nilai syarikat dapat dilihat dalam kemampuan perusahaan untuk membayar dividen. Jumlah dividen ini boleh mempengaruhi harga saham. Jika dividen dibayar tinggi, maka harga saham tunduk tinggi, sehingga nilai perusahaan juga tinggi. Sebaliknya, jika dividen kecil dibayarkan, harga saham syarikat juga rendah. Keupayaan membayar dividen sangat berkaitan dengan kemampuan syarikat untuk menghasilkan laba. Jika syarikat mendapat untung besar, maka kemampuan membayar dividen juga besar. Oleh itu, dividen yang besar akan meningkatkan nilai syarikat" (Matono dan Harjito, 2005).

"Faktor-faktor yang boleh mempengaruhi nilai syarikat adalah set peluang pelaburan (IOS), yang merupakan keputusan investasi dalam bentuk kombinasi aset yang dimiliki dan pilihan investasi di masa depan. Seperangkat peluang pelaburan akan diukur menggunakan pasaran untuk nilai buku nisbah aset. Syarikat dengan kadar peluang pelaburan yang tinggi akan mempunyai kapasiti untuk menghasilkan keuntungan yang lebih besar".

"Untuk pasar memberikan tanggapan yang lebih besar kepada perusahaan yang memiliki peluang untuk berkembang (set peluang investasi). Respons pasar yang tinggi terhadap pendapatan menunjukkan bahwa perusahaan memiliki kualitas laba yang baik" (Wulansari, 2013).

Variabel lain yang dapat mempengaruhi "nilai perusahaan adalah pengembalian modal, laba 
atas ekuitas adalah hubungan yang menunjukkan

kemampuan perusahaan untuk menghasilkan laba setelah pajak menggunakan modal sendiri perusahaan. Hubungan ini penting bagi pemegang saham untuk mengetahui efektivitas dan efisiensi manajemen modal mereka sendiri yang dilakukan oleh manajemen perusahaan" (Sudana, 2011:25).

"Semakin tinggi nilai pengembalian modal, semakin tinggi tingkat pengembalian yang diharapkan oleh pelabur. Semakin besar nilai pengembalian modal, perusahaan dianggap semakin menguntungkan. Sehingga perusahaan yang memiliki peluang investasi menguntungkan, pasar akan memberikan harga PER yang tinggi" (Sartono, 2010:41). "Pengembalian modal menunjukkan sejauh mana syarikat dapat mengurus modal sendiri secara efektif, mengukur tingkat laba dari pelaburan yang dibuat oleh pemilik modal sendiri atau pengendali pengendali perusahaan. Pengembalian modal memberikan informasi kepada investor tentang berapa besar tingkat pengembalian modal perusahaan yang disebabkan oleh kinerja perusahaan menghasilkan laba" (Aji dan Pangestuti, 2011:2).

"Berdasarkan penjelasan yang telah diuraikan di atas, maka penulis tertarik untuk melakukan penelitian mengenai pengaruh peluang investasi (set kesempatan investasi), kebijakan dividen (dividen kebijakan) dan rasio pengembalian modal (return on equity) terhadap nilai buku harga. Kajian ini bertujuan untuk mengetahui bagaimana pengaruh peluang peluang investasi (set kesempatan investasi), kebijakan dividen (dividen policy) dan rasio pengembalian modal (return on equity) terhadap nilai buku harga”. Maka penelitian itu akan diterjemahkan ke dalam tulisan tulis yang berjudul "Pengaruh
Peluang Investasi, Dividend Policy Dan Rasio Tingkat Pengembalian Modal terhadap Price Book Value (Studi Kasus Pada Perusahaan Manufaktur Periode 2010 - 2014)".

\section{B. Rummusan Massalah}

"Berdasarkan kajian latar tentang faktor faktor yang mempengaruhi nilai buku harga yang diuraikan oleh penulis, maka rumusan masalah yang dibahas antara lain":

1. Bagaimaana penngaruh peluang investasi (investment opportunity set) terhadap price book value?

2. Bagaiman pengaruh dividend policy (kebijakan deviden) terhadap price book value ?

3. Bagaimana pengaruh rasio tingkat pengembalian modal (return on equity) terhadap price book value?

4. Bagaimana pengaruh peluang investasi (investment opportunity set), dividend policy (kebijakan dividen) dan rasio tingkat pengembalian mdal (return on equity) terhadap price book value?

\section{Tuujuan Peneelitian}

"Berdasarkan latar belakang masalah dan rumusan masalah, objektif dalam kajian ini adalah seperti berikut":

1. Untuk mengetahui pengaruh peluang investasi (investment opportunity set) terhadap price book value.

2. Untuk mengetahui pengaruhnya dividend policy (kebijakan deviden) terhadap price book value.

3. Untuk mengetahui pengaruhnya rasio tingkat pengembalian modal (return on equity) terhadap price book value. 
JURNAL ILMIAH

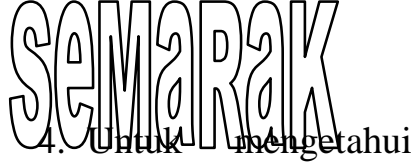

P-ISSN 2615-6849, E-ISSN 2622-3686

Jurnal Semarak,Vol. 2,No.1, Februari 2019, Hal (70- 84)

@ Prodi Manajemen Fakultas Ekonomi Universitas Pamulang

pengaruhnya peluang

investasi (investment opportunity set), dividend

policy (kebijakan dividen) dan rasio

pengembalian modal (return on equity) terhadap

price book value.

\section{TINJAUAN PUSTAKA}

\section{A. Manajemen}

"Manajemen adalah perbendaharaan kata yang berasal dari Perancis kuno, yaitu manajemen bermaksud seni menjalankan dan mengatur. Pengurusan adalah elemen asas yang akan sentiasa dalam proses pengurusan dan akan menjadi rujukan bagi pengurus dalam menjalankan aktiviti untuk mencapai objektif”.

"Menurut (Robbinss dan Coulters, 2010:6), menyatakan bahwa yang dimaksud" dengan "Manajemen adalah proses mengkoordinasi kegiatan-kegiatan pekerjaan sehingga secara efisien dan efektif dengan dan melalui orang lain". Pendapat lain diungkapkan oleh Handokko (2010:8) yang mengutip dari Stonner "management Prentice", yang mengatakan "manajemen adalah proses perencanaan, proses pengorganisasian, pengarahan dan pengawasan usaha-usaha para anggota dan penggunaan sumber daya-sumber daya organisasi lainnya agar mecapai tujuan organisasi yang telah ditetapkan".

\section{B. Manajemen Keuangan}

Sartono, (2010:6) menyatakan dalam teori yaitu "manajemen keuangan dapat diartikan sebagai manajemen dana baik yang berkaitan dengan pengalokasian dana dalam berbagai bentuk investasi secara efektif maupun usaha pengumpulan dana untuk pembiayaan investasi atau pembelanjaan secara efisien".

Husnan, (2010:3) berpendapat bahwa "manajemen keuangan adalah suatu kegiatan perencanaan, penganggaran. Pemeriksaan, pengelolaan, pengendalian, pencarian dan penyimpanan dana yang dimiliki oleh suatu organisasi atau perusahaan".

Berdasarkan pendapat para ahli sebelumnya, dapat disimpulkan bahwa manajemen keuangan merupakan "manajemen dana", baik yang terkait dengan alokasi dana dalam berbagai bentuk investasi secara efektif dengan kegiatan perencanaan, anggaran. "Verifikasi, administrasi, kontrol, mencari dan menyimpan dana yang dimiliki oleh organisasi atau syarikat. Objektif utama pengurusan kewangan syarikat adalah untuk memaksimumkan manfaat yang diperoleh dan memaksimumkan" kesejahteraan para pemegang saham, yang boleh diukur dengan harga saham syarikat".

\section{Kinerja dan Laporan Keuangan}

"Penyata kewangan adalah keputusan akhir proses perakaunan. Sebagai hasil akhir proses perakaunan, penyata kewangan menyediakan maklumat yang berguna untuk membuat keputusan oleh beberapa pihak, seperti pemilik atau pemiutang syarikat" (Suwiknyo, 2010: 42).

"Dua penyata kewangan yang secara umumnya menggunakan akruan adalah penyata keuntungan dan kerugian dan kunci kira-kira. Sementara itu, penyata aliran tunai adalah penyata kewangan yang juga berdasarkan akruan, tetapi 
telah diselaraskan untuk mencerminkan aliran tunai sebenar” (Mardiyanto, 2008: 27).

Briggham daan Housston (2010:87) "memberikan pendapat bahwa "neraca (balance sheet) adalah suatu laporan mengenai posisi keuangan perusahaan pada suatu titik tertentu)". Sedangkan menurut Reve, et, al (2009) mengatakan bahwa "neraca merupakan daftar asset, kewajiban, dan ekuitas pemilik pada waktu tertentu, biasanya pada tanggal terakhir dari bulan atau tahun tertentu". "Lembaran imbangan terdiri daripada dua pihak, iaitu sisi kanan yang menyajikan data dari nilai aset yang dimiliki oleh syarikat, manakala dari sebelah kiri menyajikan data mengenai liabiliti dan aset syarikat yang mencerminkan nilai tuntutan terhadap aset. Kunci kira-kira adalah penyata kewangan yang menggambarkan keadaan kewangan sesebuah syarikat pada masa tertentu".

Lembaran imbangan ini juga dirujuk sebagai "gambaran keseluruhan keadaan kewangan syarikat, iaitu gambar atau gambar seketika seperti gambar, kerana kunci kira-kira hanya memberikan maklumat tentang kedudukan kewangan syarikat pada masa tertentu" (Tandelilin, 2010:365-366).

(Mardiyanto, (2008:27) berpendapat bahwa "Neraca adalah laporan yang mengungkapkan posisi keuangan (kekayaan) perusahaan pada tanggal tertentu termasuk aset (asset), utang (liability) dan ekuitas (equity). Hubungan antara ketiganya disebut sebagai persamaan akuntansi, yaitu aset sama dengan utang ditambah ekuitas".

\section{Rasio - Rasio Keuangan Perusahaan}

Financial Ratio adalah "nombor yang diperoleh daripada perbandingan satu pos penyata kewangan dengan yang lain yang mempunyai hubungan yang relevan dan signifikan. Teknik ini sangat biasa digunakan oleh analisis kewangan. Nisbah kewangan adalah asas untuk menilai dan mengarahkan pencapaian operasi syarikat. Di samping itu, analisis nisbah kewangan juga dibuat berdasarkan objektif penganalisis dalam menilai prestasi syarikat berdasarkan penyata kewangan. " (Sugiono, 2009: 64).

"Penyata kewangan melaporkan aktiviti yang telah dijalankan oleh syarikat dalam tempoh tertentu. Aktiviti yang telah dijalankan dinyatakan dalam angka dalam bentuk Rupiah dan pertukaran asing. Angka-angka dalam penyata kewangan kurang bermakna jika hanya dilihat dari satu pihak. Berarti jika hanya dengan melihatnya. Nombornombor ini akan lebih banyak jika kita dapat membandingkan antara satu komponen dan komponen lain. Caranya ialah membandingkan angka dalam penyata kewangan dengan penyata kewangan lain. Selepas membuat perbandingan, anda boleh menyimpulkan kedudukan kewangan anda untuk tempoh tertentu. Akhirnya kita dapat menilai prestasi pengurusan dalam tempoh itu. Kita tahu perbandingan ini dengan nama analisis nisbah kewangan. Nisbah kewangan membantu kami mengenal pasti beberapa kelemahan dan kekuatan kewangan syarikat" (Keown, 2011: 74).

"Rasio kewangan akan menulis semula data perakaunan sebagai perbandingan untuk mengenal pasti kekuatan dan kelemahan kewangan syarikat" (Keown, 2011:74). "Rasio kewangan digunakan untuk menilai keadaan kewangan dan prestasi syarikat. Dari hasil nisbah kewangan ini, keadaan kesihatan syarikat akan dilihat" (Kasmir dan Jakfar, 2012: 104). 
Maka dapat disimpulkan bahwa "rasio

keuangan adalah kegiatan membandingkan angkaangka dalam laporan keuangan dengan membagi satu angka dengan yang lain".

"Perbandingan boleh dibuat antara satu komponen dan komponen lain dalam satu laporan kewangan. Kemudian nombor yang boleh dibandingkan boleh nombor dalam satu tempoh atau beberapa tempoh. Hasil dari nisbah ini digunakan untuk menilai prestasi pengurusan dalam satu peride sama ada ia mencapai sasaran sebagaimana ditentukan. Kemudian dapat dinilai kemampuan manajemen untuk memberdayakan sumber daya perusahaan secara efektif" (Kasmir dan Jakfar, 2012: 104).

"Dari prestasi yang dihasilkan, ia juga dapat digunakan sebagai penilaian hal-hal yang perlu dilakukan pada masa akan datang agar kinerja manajemen dapat ditingkatkan atau dikelola sesuai dengan target perusahaan. Atau dasar yang harus diambil oleh pemilik syarikat untuk membuat perubahan kepada orang yang duduk di dalam pengurusan pada masa akan datang" (Kasmir dan Jakfar, 2012:105).

\section{E. Price Book Value}

"Nilai syarikat itu boleh dianggap sebagai" kek bola ". Matlamat pengurus adalah untuk membesarkan "kek bola" yang keputusan struktur modal dapat dilihat sebagai cara yang baik untuk memotong "kue bola". "Jika cara anda memotong memberi kesan kepada" kek bola "maka keputusan struktur modal berpengaruh. Nilai syarikat adalah nilai pasaran hutang ditambah dengan nilai ekuiti pasaran " (Rodoni dan Ali, 2010:4).

"Harga saham dan nilai syarikat meringkaskan penilaian kolektif pelabur mengenai prestasi syarikat, prestasi semasa dan prospek masa depannya. Oleh itu, kenaikan harga saham menghantar isyarat positif daripada pelabur kepada pengurus. Dan ini merupakan kelebihan penting syarikat-syarikat yang pergi awam. Syarikat tertutup tidak boleh menggunakan harga saham sebagai ukuran prestasi" (Brealy, Myers dan Marcus, 2007:56).

"Beberapa konsep nilai yang menjelaskan nilai sesuatu syarikat adalah nilai nominal, nilai pasaran, nilai intrinsik, nilai buku, dan nilai pembubaran. Nilai nominal adalah nilai yang dinyatakan secara rasmi dalam artikel persatuan syarikat, yang dinyatakan secara jelas dalam lembaran imbangan syarikat, dan juga dengan jelas ditulis dalam surat perkongsian kolektif. Nilai pasaran, yang sering disebut kadar pertukaran, adalah harga yang berlaku dari proses tawar menawar di pasaran saham". Nilai intrinsik, adalah konsep paling abstrak, kerana ia merujuk kepada anggaran nilai sebenar syarikat. "Nilai syarikat dalam konsep nilai intrinsik tidak hanya harga satu set aset, tetapi nilai syarikat sebagai entiti perniagaan yang mempunyai keupayaan untuk menjana keuntungan pada masa hadapan". Walaupun nilai buku adalah nilai syarikat dikira berdasarkan konsep perakaunan. Cukup dikira dengan membahagikan perbezaan antara jumlah aset dan jumlah hutang dengan bilangan saham yang belum dijelaskan. Nilai pembubaran adalah nilai jualan semua aset syarikat selepas menolak semua kewajipan yang mesti dipenuhi”. Nilai sisa adalah sebahagian daripada pemegang saham. "Nilai pembubaran boleh dikira dengan cara yang sama seperti pengiraan nilai buku, yang 
berdasarkan lembaran imbangan pro forma yang Jurnal Semarak,Vol. 2,No.1, Februari 2019, Hal (70- 84)

@Prodi Manajemen Fakultas Ekonomi Universitas Pamulang

disediakan apabila syarikat dibubarkan" (Keown, 2008: 849).

"Nilai korporat yang tinggi adalah keinginan pemilik syarikat, kerana dengan nilai yang tinggi menunjukkan kemakmuran para pemegang saham juga akan meningkat”. Kekayaan pemegang saham dan syarikat diwakili oleh harga pasaran saham yang mencerminkan keputusan pelaburan, kebijakan dividen, dan keputusan pendanaan (Brigham and Houston, 2009: 19). Nisbah yang digunakan untuk mengukur nilai syarikat" (Mardiyanto, 2008:64):

"Nilai buku harga menggambarkan nilai pasaran nilai stok syarikat. Naik nisbah ini, pasaran percaya kepada prospek syarikat”.

\section{F. Peluang Investasi}

"Istilah Peluang Pelaburan (IOS) istilah muncul selepas dicadangkan oleh Myers (1977) melihat nilai tegas sebagai gabungan aset di tempat (aset yang dimiliki) dengan pilihan pelaburan (pilihan pelaburan) pada masa akan datang. Pilihan pelaburan adalah peluang untuk berkembang, tetapi sering syarikat tidak boleh selalu melaksanakan semua peluang pelaburan di masa depan. Bagi syarikat yang tidak boleh menggunakan peluang pelaburan, mereka akan mengalami perbelanjaan yang lebih tinggi berbanding dengan nilai peluang yang hilang" (Astriani, 2014: 4).

Kole dalam Norpratiwi

(2004:6) "menyatakan bahawa nilai set peluang pelaburan bergantung kepada perbelanjaan masa depan yang ditentukan oleh pengurusan (perbelanjaan budi bicara masa depan) yang merupakan pilihan pelaburan yang dijangka menghasilkan pulangan yang lebih besar daripada kos modal dan boleh menjana keuntungan".

"Secara umum, boleh dikatakan bahawa Set Peluang Pelaburan menggambarkan tahap peluang atau peluang pelaburan untuk syarikat, tetapi ia sangat bergantung kepada pilihan perbelanjaan syarikat demi masa depan. Oleh itu, Set Peluang Pelaburan tidak dapat diperhatikan supaya proksi itu mesti dipilih yang boleh dikaitkan dengan pemboleh ubah lain dalam keuntungan" (Norpratiwi, 2004: 8).

"Pelaburan meletakkan wang atau dana dengan harapan mendapat tambahan atau keuntungan dari dana ini. Satu kajian yang dijalankan oleh Myers (1977) di Astriani (2014: 9) yang menyatakan bahawa IOS memberikan petunjuk yang lebih luas di mana nilai syarikat bergantung kepada perbelanjaan syarikat pada masa akan datang. IOS adalah kombinasi pilihan aset yang dimiliki dan pelaburan pada masa hadapan dengan nilai semasa bersih positif. Jadi IOS adalah perbelanjaan semasa dengan jangkaan pulangan masa depan di mana pertumbuhan nilai pelaburan dapat meningkatkan nilai syarikat" (Astriani, 2014: 9).

\section{G. Dividend Policy}

"Nisbah antara dividen dan pendapatan bersih sering dirujuk sebagai nisbah pembayaran dividen (DPR). Dengan dasar ini syarikat kurang dapat menganggarkan jumlah pembayaran dividen yang akan dibuat setiap tempoh. Jumlah 
pembayaran dividen dengan peratusan tetap EPS

akan mempengaruhi kedudukan harga pangsa pasar. Apabila pendapatan berkurangan, pembayaran dividen juga berkurangan dan ini akan menyebabkan harga saham menurun juga" (Astuti, 2004:146). "Sepintas lalu, pemegang saham akan berasa gembira jika sebahagian daripada pendapatan bersih yang diagihkan sebagai dividen adalah lebih tinggi. Walau bagaimanapun, jika DPR semakin besar, maka pendapatan tertahan akan berkurangan. Oleh itu, keputusan dividen akan merujuk kepada dasar dividen optimum yang diselaraskan dengan konsep objektif untuk memaksimumkan nilai syarikat".

Rodoni dan Ali (2010:125) mengatakan bahwa "dasar dividen optimum syarikat (dasar dividen optimum) adalah dasar yang mewujudkan keseimbangan antara dividen semasa dan pertumbuhan masa depan syarikat yang memaksimumkan nilai syarikat".

Menurut teori agensi, salah satu pendekatan untuk meminimalkan masalah keagenan adalah mekanisme pembayaran dividen. Menurut Rozeff (1982) dan Mohd et. Al. (1998) dalam Haruman (2008: 151) masalah keagenan dapat dikurangi dengan mekanisme pembayaran dividen, karena dengan pemegang saham pembayaran dividen melihat bahwa manajer perusahaan telah mengambil tindakan yang sesuai dengan keinginan mereka, sehingga mengurangi konflik keagenan.

\section{H. Return on Equity}

Sudana (2011: 23) menyatakan bahawa "apa yang dimaksudkan dengan pulangan ekuiti adalah nisbah yang menunjukkan keupayaan syarikat untuk memiliki modal. Harahap (2007: 305) juga berpendapat bahawa "pulangan atas ekuiti adalah nisbah kewangan yang menunjukkan keupayaan syarikat untuk menjana keuntungan selepas cukai dengan menggunakan modal sendiri syarikat".

Return on equity adalah nisbah yang menunjukkan kejayaan pengurusan untuk memaksimumkan pulangan ke atas pemegang saham. Lebih tinggi pulangan ke atas ekuiti, lebih baik, kerana ia memberikan pulangan yang lebih besar kepada para pemegang saham (Darsono, 2005: 57). Sartono (2010: 52) menyatakan bahawa "semakin besar nilai ROE, semakin tinggi jangkaan pulangan terhadap pelabur. Semakin besar nilai ROE, syarikat dianggap semakin menguntungkan. Sehingga syarikat-syarikat yang mempunyai peluang pelaburan yang menguntungkan, pasar akan memberikan PER "adalah rasio yang menunjukkan keberhasilan manajemen untuk memaksimalkan laba atas pemegang saham. Semakin tinggi tingkat pengembalian ekuitas, semakin baik, karena memberikan pengembalian yang lebih besar bagi pemegang saham (Darsono, 2005:57). Sartono (2010:52) menyatakan bahwa "semakin besar nilai ROE, semakin tinggi pengembalian yang diharapkan pada investor. Semakin besar nilai ROE, perusahaan dianggap semakin menguntungkan. Sehingga perusahaan yang memiliki peluang investasi menguntungkan, pasar akan memberikan penghargaan PER yang tinggi”.

Riadi (2011: 2) mempunyai pendapat lain bahawa "pulangan ekuiti (ROE) adalah nisbah keuntungan untuk mengukur keupayaan sebuah syarikat untuk menghasilkan keuntungan berdasarkan modal saham syarikat. ROE digunakan untuk mengukur kadar pulangan 
syarikat atau keberkesanan syarikat dalam

@ Prodi Manajemen Fakultas Ekonomi Universitas Pamulang

menghasilkan keuntungan dengan menggunakan (return on equity) memiliki pengaruh ekuiti yang dipegang oleh syarikat ". "Jika nisbah ini meningkatkan pengurusan cenderung dilihat lebih efisien dari perspektif pemegang saham. ROE adalah nisbah antara pendapatan bersih yang dihasilkan dengan modal sendiri atau ekuiti”.

\section{Hipotesis dari Penelitian}

Hipotesis adalah suatu dugaan dalam suatu penelitian yang menjadi patokan dalam suat analisis. Adapun hipotesis yang diuji yakni sebagai berikut:

1. $\mathrm{H}_{\mathrm{o}}$ : peluang investasi (investment opportunity set) tidak memiliki pengaruh terhadap price book value.

$\mathrm{H}_{\mathrm{a}}$ : peluang investasi (investment opportunity set) memiliki pengaruh terhadap price book value.

2. $\mathrm{H}_{\mathrm{o}}$ : dividend policy (kebijakan deviden) tidak memiliki pengaruh terhadap price book value.

$\mathrm{H}_{\mathrm{a}}$ : dividend policy (kebijakan deviden) memiliki pengaruh terhadap price book value.

3. $\mathrm{H}_{\mathrm{o}}$ : rasio tingkat pengembalian (return on equity) tidak memiliki pengaruh terhadap price book value.

$\mathrm{H}_{\mathrm{a}}$ : rasio tingkat pengembalian (return on equity) memiliki pengaruh terhadap price book value.

4. $\mathrm{H}_{\mathrm{o}}$ : peluang investasi (investment opportunity set), dividend policy (kebijakan deviden) dan rasio tingkat pengembalian modal (return on equity) tidak memiliki pengaruh terhadap price book value.

$\mathrm{H}_{\mathrm{a}}$ : peluang investasi (investment opportunity set), dividend policy (kebijakan deviden) dan rasio tingkat pengembalian modal 
menggunakan tahun kewangan yang berakhir pada 31 Desember, 3) Syarikat perkilangan yang disenaraikan di Bursa Saham Indonesia, 4) syarikat pembuatan yang menyenaraikan tarikh dan mengagihkan dividen dari tahun 2010 hingga 2014.

Teknik pengumpulan data menggunakan analisis penyata kewangan. Sampel yang digunakan sebagai objek penyelidikan ialah 36 syarikat pembuatan yang disenaraikan di IDX.

\section{HASIIL DAAN PEMMBAHASAN}

\section{A. Analissa Objjek Peenelittian}

\section{Sejaarah Paasar Mooddal Di Indonesaian}

"Berdasarkan sejarah pasaran modal sebelum kemerdekaan Indonesia, pasar modal atau bursa saham telah muncul sejak era kolonial Belanda dan tepat pada tahun 1912, ketika pasar modal didirikan oleh pemerintah Hindia Belanda untuk kepentingan penjajah".

"Perkembangan pertumbuhan pasaran modal tidak berlaku seperti yang diharapkan. Dalam beberapa tempoh aktiviti pasaran modal yang mengalami kekosongan yang disebabkan oleh beberapa faktor seperti Perang Dunia I dan II, Kerajaan Republik Indonesia telah memulihkan semula pasaran modal pada tahun 1977 dan beberapa tahun kemudian pasaran modal mengalami pertumbuhan bersama dengan pelbagai insentif dan peraturan yang dikeluarkan oleh kerajaan".

\section{Perusahaan Manufaktur}

"Sebuah syarikat perkilangan adalah sebuah syarikat yang menjalankan proses pembuatan produk. Sebuah syarikat boleh dikatakan sebagai sebuah syarikat perkilangan jika ada tahap input-process-output yang pada akhirnya menghasilkan suatu produk". Pembuatan adalah cawangan perindustrian yang mengimplementasikan peralatan dan memproses media untuk menukar bahan mentah menjadi barangan siap untuk dijual. "Usaha ini melibatkan semua proses perantaraan yang diperlukan untuk pengeluaran dan integrasi komponen produk". Sesetengah industri, seperti semikonduktor dan kilang keluli, juga menggunakan istilah fabrikasi atau pembuatan. Sektor perkilangan sangat berkaitan dengan kejuruteraan".

"Ciri utama industri pembuatan ialah memproses sumber menjadi barangan siap melalui proses pembuatan. Aktiviti syarikat milik kumpulan industri pembuatan mempunyai tiga aktiviti utama".

\section{B. Hasiil Peenemuan dann Pemmbahasan}

\section{Hassil Penggujian Assumsi Klassik}

\section{a. Hassil Peengujian Norrmalitas Daata}

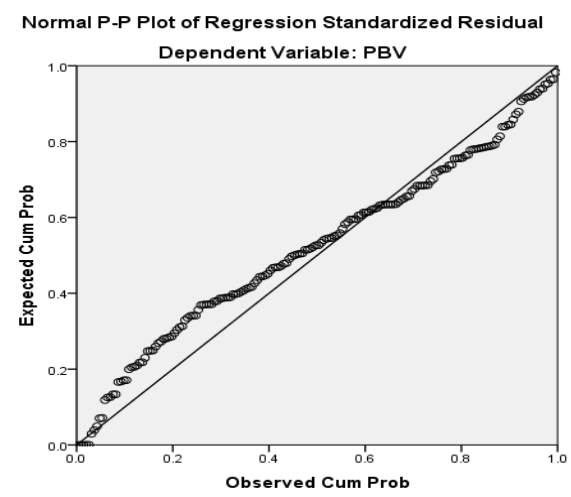

Gambar 1

Hassil Penngujian

Noormalitas Data

"Dari grafik di atas dapat dilihat bahwa data penelitian memiliki penyebaran dan distribusi yang normal karena data memusat pada nilai rata-rata dan median atau nilai plot 
dikatakan bahwa data tersebut berdistribusi normal".

\section{b. Hasil Ujji Multikollinearitas}

Tabel 1

Hasil Uji Multikollinearitas

\begin{tabular}{|c|c|c|c|}
\hline \multicolumn{4}{|c|}{ Coefficients } \\
\hline \multirow{2}{*}{\multicolumn{2}{|c|}{ Model }} & \multicolumn{2}{|c|}{$\begin{array}{l}\text { Collinearity } \\
\text { Statistics }\end{array}$} \\
\hline & & Tolerance & VIF \\
\hline \multirow{4}{*}{1} & (Constant) & & \\
\hline & 10 & .639 & 1.564 \\
\hline & $\mathrm{KD}$ & .973 & 1.028 \\
\hline & $\mathrm{ROE}$ & .644 & 1.554 \\
\hline
\end{tabular}

"Nilai VIF yang diperbolehkan di bawah 10 dan memiliki nilai tolerance di atas 0,10 . Maka data di atas dapat dipastikan tidak terjadi gejala multikolinearitas. Karena data di atas menunjukan bahwa nilai VIF sebesar 1,564 untuk variabel IO, 1,028 untuk variabel KD dan 1,554 untuk variabel ROE lebih kecil dari 10. Dan nilai tolerance di atas 0,10 yaitu sebesar 0,639 untuk variabel IO, 0,973 untuk variabel $\mathrm{KD}$ dan 0,644 untuk variabel ROE".

\section{c. Hasil Pengujian Autokorelasi}

\section{Tabel 2}

\section{Hassil Penguujian Autokoorelasi}

\begin{tabular}{|l|r|r|r|r|r|}
\hline Model & $R$ & $R$ Square & $\begin{array}{r}\text { Adjusted } \\
\text { R Square }\end{array}$ & $\begin{array}{r}\text { Std. Error of } \\
\text { the Estimate }\end{array}$ & Durbin-Watson \\
\hline 1 & $.728^{\mathrm{a}}$ & .530 & .522 & 36.00750 & 1.774 \\
\hline a. Predictors: (Constant), ROE, KD, I0 & \\
\hline
\end{tabular} b. DependentVariable:PBV

"Terlihat bahwa nilai Durbin Watson (d) sebesar 1,774 nilai ini akan dibandingkan dengan nilai tabel dengan menggunakan nilai signifikansi 5\%, jumlah sampel (n) 180 dan jumlah variabel independen $(\mathrm{k})$ adalah 3. Maka dari tabel didapat nilai du $=1,790$ dan $4-\mathrm{du}=4-1,790=2,21$. Olleh kareena nilaai $\mathrm{du}<\mathrm{d}<4$-du atau $1,774<1,790<$ 2,21 maka dapat disimpulkan tidak ada autokorelasi”.

\section{d. Hassil Ujji Heeteroskedastisitas}

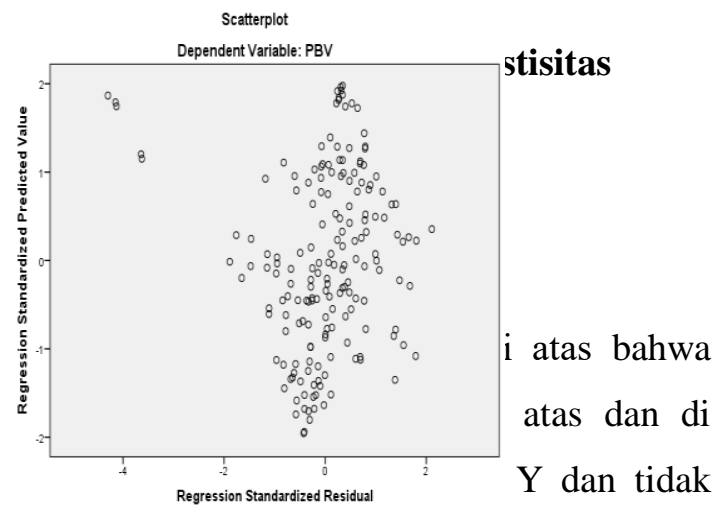

terlihat pola tertentu. Dengan demikian pada persamaan regresi linier berganda dalam model ini tidak ada gejala atau tidak ada heteroskedastisitas".

\section{Hassil Koeefisien Reegresi Liinier Beerganda}

a. Haasil Koeefisien Addjusted $\boldsymbol{R}^{2}$

Tabel 3

\section{Hassil Kooefisien Adjjusted $\mathbf{R}^{2}$}

\begin{tabular}{|l|r|r|r|r|r|}
\hline Model & $R$ & R Square & $\begin{array}{r}\text { Adjusted } \\
\text { R Square }\end{array}$ & $\begin{array}{r}\text { Std. Error of } \\
\text { the Estimate }\end{array}$ & Durbin-Watson \\
\hline 1 & $.728^{\mathrm{a}}$ & .530 & .522 & 36.00750 & 1.774 \\
\hline a. Predictors: (Constant), ROE, KD, 10 \\
b. DependenttVariable:PBV
\end{tabular}

"Berdasarkan kepada tabel di atas diketahui nilai Adjusted $R$ square sebesar 0,522 (52,2\%), Ini menunjukkan bahwa dengan menggunakan model regresi yang didapatkan dimana variabel independen yaitu investment opportunity set, kebijakan deviden dan return on equity memiliki pengaruh terhadap variabel price book value sebesar $52,2 \%$. Sedangkan sisanya $47,8 \%$ dijelaskan dengan faktor atau variabel lain yang tidak diketahui dan tidak termasuk 
earning ratio, firm size dan lain-lain".

\section{b. Hasil Koefisien Perrsamaan Regressi Liniier Bergaanda}

Analisis regresi linier berganda ialah ujian yang digunakan untuk menentukan sejauh mana tahap pengaruh antara pembolehubah bebas (set peluang pelaburan, dasar dividen dan pulangan ke atas ekuiti) ke atas pembolehubah bergantung (nilai buku harga). Hasil daripada pengaruh regresi linear berganda bagi set peluang pelaburan, dasar dividen dan pulangan ke atas ekuiti terhadap nilai buku harga adalah seperti berikut:

\section{Tabel 4}

Hasil daripada Koefisien Persamaan Regresi Pelbagai Linear

\begin{tabular}{|c|c|c|c|c|c|c|}
\hline \multicolumn{7}{|c|}{ Coefficients } \\
\hline \multirow[t]{2}{*}{ Model } & & \multicolumn{2}{|c|}{$\begin{array}{c}\text { Unstandardized } \\
\text { Coefficients }\end{array}$} & \multirow{2}{*}{\begin{tabular}{c|}
$\begin{array}{c}\text { Standardized } \\
\text { Coefficients }\end{array}$ \\
Beta \\
\end{tabular}} & \multirow[t]{2}{*}{$t$} & \multirow[t]{2}{*}{ Sig. } \\
\hline & & $B$ & Std. Error & & & \\
\hline \multirow{4}{*}{1} & (Constant) & 8.943 & 7.041 & & 1.270 & .206 \\
\hline & 10 & 273 & .065 & .273 & 4.222 & .000 \\
\hline & KD & .130 & .052 & .130 & 2.479 & .014 \\
\hline & ROE & .499 & .064 & .499 & 7.743 & .000 \\
\hline
\end{tabular}

Jadual di atas boleh dirumuskan persamaan regresi untuk menentukan kesan set peluang pelaburan, dasar dividen dan pulangan ekuiti ke arah nilai buku harga seperti berikut:

$\mathrm{Y}=\mathrm{a}+\mathrm{bx}_{1}+\mathrm{bx}_{2}+b \mathrm{x}_{3}+\mathrm{bx}$

$Y=8,943+0,273 X_{1}+0,130 X_{2}+0,499 X_{3}$

Keterangan:

Y : Price Bok Value

$\mathrm{X}_{1}$ : Invesstment Oportunity Seet

$\mathrm{X}_{2}$ : Keebijakan Dividen

$\mathrm{X}_{3}$ : Retuurn onn Eqquity
"Koefisien persamaan regresi linear berganda di atas boleh ditafsirkan sebagai pekali regresi malar 8.943 yang menunjukkan bahawa jika peluang pelaburan yang ditetapkan berubah, dasar dividen dan pulangan atas ekuiti adalah sifar, nilai nilai buku harga adalah 8.943 unit. Perhatikan bahawa pembolehubah lain dianggap malar. Pelbagai pemboleh ubah menetapkan 0.273 menunjukkan bahawa jika pemboleh ubah set yang berubah setakat meningkat sebanyak 1 unit, ia akan meningkatkan nilai buku harga sebanyak 0.273 unit. Dasar dividen berubah 0.130 menunjukkan bahawa jika pembolehubah dasar dividen meningkat sebanyak 1 unit, ia akan meningkatkan nilai buku harga sebanyak 0.130 unit. Pulangan ke atas pembolehubah ekuiti 0.499 menunjukkan bahawa jika pulangan atas vaiabel ekuiti meningkat sebanyak 1 unit, ia akan meningkatkan nilai buku harga sebanyak 0.499 unit, dengan syarat bahawa pembolehubah lain dianggap tetap"

\section{Hasil Uji Hipotesis}

\section{a. Hasil Uji Statistik F (Simultan)}

Ujian $\mathrm{F}$ dilakukan untuk melihat kesan pemboleh ubah set yang berpotensi pelaburan, dasar dividen dan pulangan ekuiti keseluruhan pada pembolehubah nilai buku harga. Berikut adalah keputusan ujian serentak, keputusan ujian ANOVA diperolehi seperti berikut:

Tabel 5

Hasil Uji Statistik F (Simultan)

\begin{tabular}{|c|c|c|c|c|c|c|}
\hline \multicolumn{7}{|c|}{ ANOVA } \\
\hline Model & & Sum of Squares & $d f$ & Mean Square & $\bar{F}$ & Sig. \\
\hline \multirow{3}{*}{1} & Regression & 257785.395 & 3 & 85928.465 & 66.275 & $.000^{\circ}$ \\
\hline & Residual & 228191.105 & 176 & 1296.540 & & \\
\hline & Total & 485976.500 & 179 & & & \\
\hline
\end{tabular}


Daripada data di atas memperoleh nilai signifikan 0,000 bermakna bahawa peruntukan nombor dua terpakai dalam kajian ini yang Ho ditolak dan Ha diterima. Keputusan ujian $\mathrm{F}$ ini menyatakan bahawa keputusan ujian serentak di atas adalah benar.

Dalam kajian ini, nilai $\mathrm{F}$ yang dikira daripada 66.275 adalah lebih tinggi daripada nilai Ftable 2.66. Boleh disimpulkan bahawa terdapat kesan linear antara pembolehubah bebas dan pembolehubah bergantung.

\section{b. Hasil Uji t (Uji Secara Parsial)}

\section{Tabel 6}

Hasil Uji t (Uji Secara Parsial)

\begin{tabular}{|c|c|c|c|c|c|c|}
\hline \multicolumn{7}{|c|}{ Coefficients ${ }^{\text {i }}$} \\
\hline \multirow[t]{2}{*}{ Mode } & & \multicolumn{2}{|c|}{$\begin{array}{l}\text { Unstandardized } \\
\text { Coefficients }\end{array}$} & \multirow{2}{*}{\begin{tabular}{c|}
$\begin{array}{c}\text { Standardized } \\
\text { Coefficients }\end{array}$ \\
Beta \\
\end{tabular}} & \multirow[t]{2}{*}{ t } & \multirow[t]{2}{*}{ Sig. } \\
\hline & & $B$ & Std. Error & & & \\
\hline \multirow{4}{*}{1} & (Constant) & 8.943 & 7.041 & & 1.270 & .206 \\
\hline & 10 & 273 & .065 & 273 & 4.222 & .000 \\
\hline & $\mathrm{KD}$ & .130 & .052 & .130 & 2.479 & .014 \\
\hline & ROE & 499 & .064 & 499 & 7.743 & .000 \\
\hline
\end{tabular}

Berdasarkan keputusan ujian t, didapati bahawa variabel bebas (set peluang pelaburan, dasar dividen dan pulangan ke atas ekuiti) mempunyai kesan separa pada nilai buku harga.

\section{KESIIMPULAN DANN SARRAN}

\section{A. Kesimmpulan}

Kajian ini dijalankan untuk menentukan kesan set peluang pelaburan, dasar dividen dan pulangan ekuiti pada nilai buku harga. Berdasarkan hasil penyelidikan yang dijelaskan dalam bab sebelumnya, beberapa kesimpulan dapat diambil seperti berikut:
1. Hasil kajian menyatakan bahawa sebahagian atau berdasarkan keputusan ujian $t$ menunjukkan bahawa pemboleh ubah set yang berpotensi pelaburan mempengaruhi nilai buku harga.

2. Hasil kajian menyatakan bahawa sebahagian atau berdasarkan hasil uji $\mathrm{t}$ menunjukkan bahawa dasar dividen mempengaruhi nilai buku harga.

3. Hasil kajian menyatakan bahawa sebahagian atau berdasarkan hasil ujian $\mathrm{t}$ menunjukkan bahawa pulangan atau perubahan ekuiti mempengaruhi nilai buku harga.

4. Hasil kajian menyatakan bahawa secara serentak atau berdasarkan keputusan ujian $\mathrm{F}$ menunjukkan terdapat pengaruh yang signifikan antara set peluang pelaburan berubah-ubah, dasar dividen dan pulangan ke atas ekuiti terhadap nilai buku harga.

\section{B. Saran}

Hasil kajian ingin memberikan beberapa cadangan yang dapat disampaikan, iaitu:

1. Saran Bagi Investor

Secara umum, hampir semua pelaburan mengandungi ketidakpastian. Pelabur tidak tahu pasti keputusan yang akan diperolehi daripada pelaburan yang dibuat. Kerana pelabur menghadapi peluang pelaburan berisiko, pilihan pelaburan tidak boleh bergantung semata-mata pada tahap keuntungan tetapi pelabur mesti bersedia menanggung risiko pelaburan mereka. Oleh itu, dalam pelaburan, pelabur perlu menimbangkan dengan berhati-hati tentang beberapa perkara yang sangat penting dalam membuat keputusan pelaburan yang mereka 
Jurnal Semarak,Vol. 2,No.1, Februari 2019, Hal (70- 84)

@Prodi Manajemen Fakultas Ekonomi Universitas Pamulang

lebih baik sekali lagi dan untuk mengetahui

Brigham, Eugene F and Joel F.Houston, "Dasar-dasar Manajemen Keuangan", Salemba Empat, Jakarta, 2010.

perubahan supaya mereka tidak salah dalam

melabur.

2. Saran Bagi Perusahaan

Hasil kajian ini boleh digunakan sebagai maklumat dan pertimbangan tambahan bagi syarikat dalam menjalankan kebijakan yang berkaitan dengan pelaburan. Dan bagi syarikatsyarikat untuk terus meningkatkan usaha mereka supaya pelabur melabur saham mereka.

3. Saran Bagi Akademis

Penilaian analisis analisis pengaruh peluang pelaburan, dasar dividen dan pulangan ekuiti yang mempengaruhi nilai buku harga boleh digunakan sebagai pengetahuan tambahan untuk penyelidikan masa depan. Dan lakukan penyelidikan yang lebih baik dan meningkatkan jumlah pembolehubah dan tempoh penyelidikan untuk menghasilkan data yang lebih baik, kerana masih ada 47.8 persen dari variabel yang dapat mempengaruhi nilai buku harga.

\section{DAFTAR PUSTAKA}

Astriani, Eno Fuji, "Pengaruh Kepemilikan Manajerial, Leverage, Profitabilitas, Ukuran Perusahaan dan Investment Opportunity Set terhadap Nilai Perusahaan", Jurnal Manjaemen Keuangan, Padang, 2014

Astuti, Dewi, "Manajemen Keuangan Perusahaan", Cetakan Pertama, Ghalia Indonesia, Jakarta, 2004.

Brigham, Eugene F and Joel F.Houston, "DasarDasar Manajemen Keuangan, alih bahasa Ali Akbar Yulianto", Buku satu, Edisi sepuluh, PT. Salemba Empat, Jakarta, 2009.

Darsono dan Ashari, "Pedoman Praktis Memahami Laporan Keuangan”, Andi, Yogyakarta, 2005.

Djabid, Abdullah W, "Kebijakan Dividen dan Struktur Kepemilikan Terhadap Kebijakan Hutang: Sebuah Perspektif Agency Theory", Jurnal Keuangan dan Perbankan”. Vol. 13 No. 2 Mei 2009, hal. 249-259, 2009.

Harahap, Sofyan Syafri, "Analisis Kritis atas Laporan Keuangan”, Raja Grafindo, Persada, Jakarta, 2007.

Haruman Tendi, "Pengaruh Struktur Kepemilikan Terhadap Keputusan Keuangan dan Nilai Perusahaan". Simposium Nasional Akuntansi XI, Pontianak, 2008.

Keown, J Arthur, dkk, "Dasar - Dasar Manajemen Keuangan”, Salemba Empat, Jakarta, 2004.

Keown, J Arthur, dkk, Manajemen Keuangan, Edisi 10, PT. Macanan Jaya Cemerlang, Jakarta, 2008.

Kuncoro, Mudrajad, "Metode Kuantitatif Teori dan Aplikasi Untuk Bisnis dan Ekoomi", UPP STIM YKPN, Yogyakarta, 2011.

Mardiyanto, Handono, "Intisari Manjaemen Keuangan”, Grasindo, Jakarta, 2008.

Margaretha Farah dan Asmariani Andhini. "FaktorFaktor Agency Theory yang mempengaruhi Hutang”, Media Riset dan Bisnis, Vol.9 No. 1, April, pp.1-20, 2009.

Martono dan Harjito, Agus, "Manajemen Keuangan", Ekonisia Kampus Fakultas Ekonomi UII, Yogyakarta, 2005.

Riadi Elon Davit, "Pengaruh Faktor Debt To Equity Ratio, Return On Equity Dan Total Assets Terhadap Price Earning Ratio (PER)Pada Perusahaan Otomotif”, Jurnal Ekonomi dan Bisnis, Vol. 2, Nomor 3, Tahun 2011, Padang, 2011.

Rodoni Ahmad dan Herni Ali. "Manajemen Keuangan", Edisi 1, Mitra Wacana Media, Jakarta, 2010. 
JURNAL ILMIAH

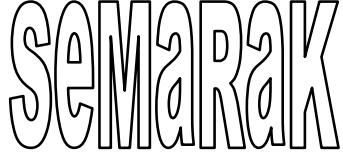

Sartono, Agus,"Manajemen Keuangan Teori dan Aplikasi”, BPEF, Yogyakarta, 2010.

Sudana, I Made, "Manajemen Keuangan Perusahaan: Teori dan Praktik”, Erlangga, Jakarta, 2011.

Suwiknyo, Dwi, "Analisis Laporan Keuangan Perbankan Syariah", Pustaka Pelajar, Yogyakarta, 2010.

Tandelilin Eduardus, "Portofolio dan Investasi Teori dan Aplikasi”, Kanisius, Yogyakarta, 2010.

Wulansari, Yenni, "Pengaruh Investment Opportunity Set, Likuiditas dan Leverage terhadap Kualitas Laba pada Perusahaan Manufaktur yang Terdaftar di BEI", JUrnal Manjemen, Padang, 2013.

Yama, indo Nasaruddin dan Septian Adityawati. "Perbandingan Analisis Karakteristik Perusahaan, Industri dan Ekonomi Makro Terhadap Return dan Beta Saham (Studi Kasus IHSG dan JII Tahun 2003 - 2008", Jurnal Ekonomi UIN Syarif Hidayatullah Jakarta, 2009. 